\title{
Rollos nacionales
}

\section{Aula Poética}

— POETIC CLASSROOM

aULA POÉTICA

Viviana Alexandra Pedroza Peña* / vialexa84@gmail.com

Mileydi Henao Rodríguez** / mifia770214@gmail.com

\section{Resumen}

El presente trabajo de investigación parte de los conceptos experiencia estética y experiencia de lectura, suscitados a partir del encuentro poético en el aula. Las concepciones teóricas que se trabajaron giran en torno a la didáctica del poema, el fenómeno poético y a la estética de la recepción y su afectación en el lector. Exaltando así la emoción que acontece en los estudiantes al momento de acercarse al texto poético. El placer de leer y escuchar poesía conlleva a provocar experiencias donde la imaginación, la sensibilidad y el conocimiento forman una amalgama propia de la condición humana.

\section{Abstract}

This research project takes into account the concepts of aesthetic experience and reading experience, which emerge from the poetic encounter in the classroom. The theoretical constructs examined in the research project are related to the didactics of poetry, the poetic phenomenon, and the aesthetics of reception and how it affects the reader, highlighting thus the emotions expressed by students when reading poetical texts. The pleasure of reading and listening to poetry leads to generating experiences where imagination, sensitivity, and knowledge form an amalgam proper to the human condition.

\section{Resumo}

O presente trabalho de pesquisa se baseia nos conceitos experiência estética e experiência de leitura, suscitados a partir do encontro poético na sala de aula. As conceições teóricas que foram trabalhadas giram em torno da didática do poema, o fenômeno poético e a estética da recepção e sua afetação no leitor, exaltando, assim, a emoção que acontece nos estudantes no momento de estudar o texto poético. O prazer de ler e escutar poesia provoca experiências onde a imaginação, a sensibilidade e o conhecimento formam uma amalgama própria da condição humana.

\section{Palabras clave}

Aula poética, experiencia estética, poesía, sensibilidad, didáctica, pedagogía de la imaginación

\section{Keywords}

Poetic classroom, aesthetic experience, poetry, sensitivity, didactics.

\section{Palavras chave}

Aula poética, experiência estética, poesia, sensibilidade, didática

Licenciada en Educación básica con énfasis en Humanidades y lengua castellana, Universidad Francisco José de Caldas. Docente de básica primaria, Secretaría de Educación de Bogotá. Magíster en Comunicación-Educación, Universidad Francisco José de Caldas.

** Licenciada en Lingüística y Literatura, Universidad Francisco José de Caldas. Docente de Humanidades y lengua castellana, Secretaría de Educación de Bogotá. Magíster en Comunicación-Educación, Universidad Francisco José de Caldas.

Fecha de recepción: 14 de marzo de 2016 / Fecha de aprobación: 01 de junio de 2016 


\section{Introducción}

La enseñanza de la literatura en las escuelas colombianas -particularmente, en las públicas- se encuentra supeditada a la asignatura de lenguaje. Quizá, esa unión sea una de las razones por las cuales la literatura no tiene un espacio suficiente en las aulas, y se mezcla con actividades de gramática u ortografía, que si bien son de vital importancia, también deberían tener un lugar separado de la enseñanza de la literatura en el currículo.

Ahora bien, si este es el panorama de la literatura, ¿qué decir del poema? La enseñanza de la poesía dentro del contexto escolar se ha convertido en una situación que, generalmente, se caracteriza por estar en dos extremos: el primero, donde se encuentran los docentes que en realidad tienen un interés profundo en esta; y el polo opuesto, el cual ocupan quienes se interesan en ella por requisito y no cuentan con la manera acertada de abordarla dentro de su quehacer pedagógico (Frost, 2013). Las dos situaciones enunciadas conllevan reflexionar en torno al papel de la poesía en la escuela y las formas de evocarla dentro del aula.

Traer al aula la poesía lleva consigo un reconocimiento del ser humano a la escuela. Afirmarlo no está en contraposición con el pensamiento científico que prevalece desde el imperio de la razón; por el contrario, al poner al ser humano al tablero hace que el pensamiento racionalista se complemente. En el presente artículo se expone una posible forma de abordar el texto poético en el aula de clase entablando un diálogo con los conceptos que abarcan la didáctica de la poesía, el fenómeno poético y la experiencia estética.

Este escrito nace como resultado del proyecto de investigación de tipo cualitativo, con una metodología de observación participativa. Partiendo de una base teórica, se describieron situaciones de aula en las cuales la experiencia poética era protagonista. Los estudiantes del grado 901 de la Jornada Tarde del Colegio Distrital Francisco Javier Matiz, ubicado en la ciudad de Bogotá, vivenciaron un encuentro con la poesía que les permitió acercamientos poéticos partiendo de la sensibilidad poética y de actos de comprensión que llevaron al desarrollo de una experiencia estética.

\section{Pedagogía de la imaginación}

A lo largo de las últimas décadas, los docentes no han parado de dialogar sobre la importancia de la lectura en el aula, y llegan al consenso de su importancia dentro de ella para la adquisición del conocimiento, así como para la actitud crítica y creativa frente al mundo. Por supuesto, los profesores de literatura no han sido ajenos a esta discusión; es más, en muchas ocasiones, en la escuela se piensa que es responsabilidad de ellos construir el hábito y el brindar herramientas para la comprensión de textos. Mientras tanto, para los docentes de lengua castellana, la literatura se ha convertido en simples ejercicios de pregunta/respuesta de corte estructuralista; es decir, la literatura es abordada con preguntas o actividades tales como: ¿Quiénes son los personajes? o Escriba el tiempo histórico descrito en la obra, entre otras preguntas.

En su texto La experiencia de la lectura, Jorge Larrosa (1996) habla sobre la lectura como una posibilidad de re-significar el mundo, y no como la simple comprensión de este. Y es aquí donde el poema encuentra un lugar apropiado en el aula: en la mirada del mundo desde otro punto de vista. El texto poético en el salón de clase lleva y guía a los estudiantes a una re-significación del mundo que los rodea. En la lectura que realizan, confrontan sus conocimientos y reconstruyen su ser desde adentro; como dice un poema de Gioconda Belli (2011, p.33), "(...) volteándome de adentro hacia afuera".

El ser se revela en la poesía; por lo tanto, construir el poelector va ligado con la finalidad de construir y potencializar la imaginación y con la hermenéutica, desde lo ontológico y lo antropológico (Goyes, 2012). En su texto La imaginación poética: afectos y efectos en la oralidad, la imagen, la lectura y la escritura, el autor Julio César Goyes define al poelector como un lector que posee las habilidades de ser crítico y creativo. Esto significaría que el poema atraviesa el ojo y conecta al poelector con el universo y su interpretación. En dicha interpretación, los sentidos están involucrados junto con todo su ser. El lenguaje poético presenta un tejido de hilos simbólicos que el lector configura y desconfigura, que se vuelven parte de su ser. 


parece verde
es verde
¿es verde?
Sí, es verde
Verde
¿te gusta el verde?
me gusta el verde
¿cualquier verde?
no, el verde solamente
¿por qué el verde?
porque es verde
¿y si no fuera verde?
no, sólo me gusta el verde
¿sólo el verde entonces?
sí, solo el verde
es lindo el verde
sí, el verde es lindo
claro, el verde
sí, el verde.

Silencio

María Mercedes Carranza (1995)

Al realizar la lectura del texto de María Mercedes Carranza, el poelector utiliza la sonoridad, el oído, para volver el silencio-verde; el juego de palabras que presenta el poema hace que entre al ser y se convierta en una experiencia. El estudiante que se guía hacia un poelector practica el silencio verde. Se refiere esto último a quien escucha con su cuerpo, su alma y su conocimiento el rumor del universo. Este silencio verde que gusta hacia un estado de reflexión y de imaginación. "El Poelector habita en la imaginación, presiente, devela, sugiere en y a través del lenguaje poético" (Goyes, 2012, p. 206). Al preguntarles a los estudiantes del grado noveno del Colegio Francisco Javier Matiz, jornada tarde, sobre sus acercamientos a la poesía en el espacio educativo, casi en su mayoría concuerdan en que la poesía era utilizada para ser declamada y escuchada; y su fin no puede ser exclusivamente ese: debe entrar primero al cuerpo, una especie de entropía, girar hacia el lector mismo, y es en el escuchar y en el silencio donde se encuentra esta fuerza poética. En otras palabras, la lectura silenciosa Ileva a encontrar el sentido personal, a volverse "hacia sí mismo" (Larrosa, 1996, p. 256). En el poema de María Mercedes Carranza, cuando se hace la primera lectura muda (Bachelard, 2012), los poelectores encuentran los tonos adecuados. En una segunda lectura es necesaria la voz, esa voluntad de hablar. Estas ideas de Bachelard van muy unidas con la sugerida por Goyes, de practicar el silencio en el aula.
Si una de las finalidades de la educación es el encuentro con el ser humano, la función del maestro sería la de provocador, la de incitador, para tomar el camino de cada ser humano que pasa por las aulas. Durante este trabajo de investigación se pensó en los poemas que se iban a implementar en el aula poética, y surgió inmediatamente la pregunta: ¿cuáles son los gustos de los estudiantes? Sin embargo, se consideró que el gusto debería pasar por los docentes que iban a guiar este trabajo en el aula. Así pues, lo primero que se debe pensar es en la experiencia que tiene el docente frente a la lectura, y, en especial, frente a la lectura de poemas. En otras palabras, recuperar el sentimiento lúdico, la imaginación, e invitar a seres humanos desde las tres estancias - corporal, afectiva y cognitiva- (Goyes, 2012) al encuentro de "sí mismos". Esta es la labor del docente en la pedagogía de la imaginación.

\section{Poesía y escuela: didáctica del poema}

El texto poético dentro del aula ofrece la posibilidad al estudiante de conocer y aprender. No obstante, muchos educandos (e, incluso, maestros) desconocen qué aporta el poema al ámbito educativo. Pues bien, el poema incluido dentro de la práctica escolar y trabajado de una manera frecuente motiva en quien tiene contacto con él una manera diferente de entender y ver el mundo; también recrea una nueva forma de usar el lenguaje, propicia la experiencia estética educando la sensibilidad y da cuenta del lenguaje poético como medio para entender la condición humana (Vásquez, 2014).

La forma de acercarse a la realidad tras la lectura del poema cambia la percepción de las cosas, como primera medida, porque involucra dos miradas: la inteligible y la emocional. La escuela motiva el pensamiento lógico-racional, y olvida, de cierta manera, lo emotivo. Sin embargo, la lectura de un poema pone en juego los dos elementos, recrea una ambigüedad donde lo íntimo y lo universal, como también la intuición y el análisis, confluyen (Vásquez, 2002). En ese sentido, el poema abre la mente a conocer y entender la realidad desde la emoción poética; en otros términos, da la oportunidad de reconocer lo particular de los seres y los objetos.

Otro cambio en tal acercamiento, es el referido a la condición humana; los lectores Ilegan a comprender que 
el lenguaje poético es un medio universal de expresión y comunicación, mediante el cual el hombre busca expresar lo que acontece en su interior y cuanto interpreta del mundo. La poesía recuerda al hombre su paso por la vida y las situaciones que se derivan de esta. Leer poesía es vivenciar que el ser humano está hecho de pasiones, sentimientos y experiencias. En concreto, es comprender que se es mortal, pero lo importante es significar y dar sentido a la existencia. En palabras de Vásquez (2002):

La poesía posee la virtud para ofrecernos de la vida su ángulo más genuino, su gesto más particular. Gracias a la poesía, adquirimos otro mirador, otros lentes para poder apreciar lo imperceptible a primera vista, o aquello otro que -por cotidiano- ya nos parece obvio; como también un tacto especial para aprecia la textura de los afectos o los sentimientos y, más aún, un gusto finísimo para lograr saborear el dolor, la ausencia la soledad... La poesía nos permea de otra piel, de otros sentidos. Nos hace mucho más sensibles y, por ello más humanos. (p. 231).

Los aspectos enunciados porVásquez permiten reflexionar en torno a la incidencia de la poesía en el hombre, conllevan pensar en los elementos subyacentes a la condición humana: afectos, sentimientos, eso que es intrínseco al ser y que logra su manifestación mediante la poesía. Elementos presentes en el poema El día de tu santo:

\footnotetext{
El día de tu santo te hicieron regalos muy valiosos: un perfume extranjero, una sortija, un lapicero de oro, unos patines, unos tenis Nike y una bicicleta. Yo solamente te pude traer, en una caja antigua de color rapé, un montón de semillas de naranjo, de pino, de cedro, de araucaria, de bellísima, de caobo y de amarillo.

Esas semillas son pacientes y esperan su lugar y su tiempo.

Yo no tenía dinero para comprarte algo lujoso. Yo simplemente quise regalarte un bosque.

El día de tu santo Jairo Aníbal Niño (1986)
}

Tras la lectura del poema El día de tu santo, el lector tiene el referente de un hecho cotidiano que acontece a todas las personas: cumplir años y los ritos sociales que de este acto se desprenden: fiestas, celebraciones y regalos. Este último elemento, los regalos, es el objeto que suscita la temática del poema. Hablar de obsequios en una sociedad de consumo conlleva pensar en elementos con un valor económico, objetos tangibles, tal como se propone en los versos, 3, 4 y 5: "un perfume extranjero, una sortija, un lapicero de oro, unos patines, unos tenis Nike y una bicicleta"; no obstante, la introducción de un elemento distinto, como las semillas, cambia la perspectiva de la lectura, pues ya no prima lo económico, y el lector es llevado a pensar en el valor de lo esencial. El regalo se traspasó al ámbito de lo emotivo y lo significativo para el ser; apela a lo bello de la naturaleza, pues, visto a los ojos del lector, ¿quién regala un bosque? Niño no hace referencia a regalar un bosque de forma literal, recurso que debe ser descubierto por el lector, pues deja de recrear hechos cotidianos para él y su lectura es sorprendida por una metáfora. En ese sentido, el lector de poesía se ubica en dos espacios: lo inteligible y lo emocional; la idea de valor es trasfigurada de lo lujoso a lo significativo.

Para lograr ese cambio de sentido, el lector tiene que realizar un proceso de interpretación distinto: la lectura no es literal, es necesario entender la metáfora y comprender por qué las semillas representan un bosque, por qué se hace alusión al tiempo y, finalmente, descubrir que el regalo escapa a cuanto se pueda comprar con dinero: "Yo no tenía dinero para comprarte algo lujoso"; el receptor de Niño comprende que las semillas personifican el trascurrir del tiempo, lo maravilloso y lo diverso de la naturaleza y el nacimiento del bosque tras la siembra y el cuidado constante y prolongado de las semillas, que, posiblemente, germinen en el corazón de quien recibe el regalo. Es de esa manera como se logra entender cuán valioso y significativo es el regalo, y el verso "Yo simplemente quise regalarte un bosque" escapa completamente a la enunciación de simple. Es así como el poema El día de tu santo es un ejemplo del proceso que se lleva a cabo mientras se lee poesía. 
Permitir que la poesía ingrese a los salones escolares no es una tarea fácil para el docente, pero depende, principalmente, de él. Que la poesía tome valor en el aula y los estudiantes la lean, la disfruten y se interesen por ella es el resultado de un trabajo consciente y bien planeado. Para ello, el maestro tiene la posibilidad de iniciar con la lectura de poemas, como una actividad diaria, sin que esta se ate a actividades de evaluación ni responda a requerimientos curriculares; de esa manera, logrará que los estudiantes acostumbren su oído al poema y se familiaricen con dicho lenguaje. En este punto, es esencial el manejo de la voz por parte del maestro, ya que será la herramienta mediante la cual va a trasmitir el poema y a enamorar a sus educandos.

Otra manera de introducir el poema en los espacios escolares es mediante la lúdica, ya que, en términos generales, el poema ha estado ligado al requerimiento curricular y a actividades monótonas, y el juego es una experiencia cultural que abre posibilidades, que favorece la incertidumbre, el caos, los conocimientos, los saberes, y, con ello, la creatividad del hombre (Jiménez, 2004). Entonces, ¿por qué no hacer una amalgama del juego y el poema? En ese sentido, es válido hacer del texto poético una posibilidad de entretenimiento y diversión, ponerlo de la mano con el juego y hacer que ronde por las actividades propias de los niños y los jóvenes.

El taller literario es también una estrategia didáctica para educar en poesía (Vásquez, 2002). Requiere un trabajo bien planeado por parte del maestro, que se enmarca dentro de una preproducción y una posproducción, lo cual quiere decir que es un proceso que surge de una necesidad o de un interés pedagógico. El taller requiere plantear objetivos, definir materiales y herramientas, propiciar espacios y tiempos. En cuanto al estudiante, debe permitirle aplicar un conocimiento previamente adquirido; es importante proponer modelos que guíen su camino y lo conduzcan a hallar su estilo propio. Es fundamental que el taller incida en el estudiante, que lo lleve a producir textos, dibujos, canciones; en fin, que tenga un espacio de poiesis. Pero, sobre todo, debe lograr cambiar en algo a los educandos. Este último no debe salir del aula como entró. Finalmente, es válido recordar que el taller no solo debe ser planeado, sino que requiere ser ejecutado y evaluado o retroalimentado con la intención de determinar si se cumplieron los objetivos planteados por el docente.

\begin{abstract}
Niño, vamos a cantar una bonita canción; yo te voy a preguntar, tú me vas a responder:

Los ojos, ¿para qué son? Los ojos son para ver. ¿Y el tacto? Para tocar. ¿Y el oído? Para oír. ¿Y el gusto? Para gustar. ¿Y el olfato? Para oler. ¿El alma? Para sentir, para querer $y$ pensar
\end{abstract}

Vamos a cantar Amado Nervo (1997).

El poema Vamos a cantar, de Nervo, es un texto a partir del cual el docente puede dar inicio a una lúdica muy sencilla. Inicialmente, la lectura del poema, acompañada de un buen uso de voz, entonando adecuadamente las preguntas y las respuestas, con el fin de diferenciar las dos voces presentes en el poema. En un segundo momento, el docente enuncia las preguntas, pero son sus estudiantes quienes dan las respuestas, y así hacen parte de la recreación del texto. Posteriormente, es viable proponer el cambio de la temática de las preguntas, no interrogar sobre los sentidos. En este punto, es importante que la nueva temática sea propuesta por los alumnos. Por último, el poema puede ser interpretado en forma de canción. Para ello, se pueden establecer grupos, quienes se encargarán de dar musicalidad al poema y presentarlo a sus compañeros.

\section{El fenómeno poético y el poema}

Entrar a definir el fenómeno poético desde una perspectiva teórica es un acto complejo. En primer lugar, porque lo poético no es un "algo" que pueda concretarse en términos teóricos, y en segundo lugar, porque escapa a la lógica. Siendo así, se deben integrar elementos propios de la existencia del hombre, como la subjetividad, la irracionalidad y la experiencia. En esa medida, no se pretende definir lo poético: más bien, se quiere hacer un acercamiento a lo poético y a la revelación de dicho fenómeno.

\footnotetext{
Busqué un azul de amanecer Para poder sentir mi cuerpo $Y$ así fui armando la vigilia Lo fui dejando junto al miedo
} 
Quise no ser una vez más

$Y$ sin embargo sigo siendo

Cuando los ojos se me cierren

Me quedaré otra vez sin cuerpo

Sueño y vigilia

Mario Benedetti (2001)

Lo poético se enmarca dentro de la creación y la contemplación de los hechos artísticos: una pintura, una escultura, una obra literaria... Pero también se encuentra presente, como lo inspira Benedetti, en la admiración de un "azul amanecer", de un sentir de hombre, entre la vida y la muerte o entre el sueño y la vigilia. Es detener la mirada en un momento determinado: "Y sin embargo sigo siendo". Encontrarse con lo bello, con lo que produce asombro, lo que le permite al hombre, por un instante, escapar de lo rutinario, de lo convencional, y poder de esa manera disfrutar de lo sublime (Paz, 2003). El poema de Mario Benedetti muestra que lo poético se encuentra no solo en las obras literarias, sino en la meditación continua del tiempo: la cotidianidad.

El poema es una posibilidad que nace de la poesía, es el lenguaje, la palabra hecha obra; en él se contiene toda la carga de lo que los poetas quieren expresar, se escapa a la lengua cotidiana y en sus versos se revela el encuentro mágico con lo sublime, con la voz del hombre.

Dales la vuelta,
Cógelas del rabo (chillen putas),
Azótalas,
Dales azúcar en la boca a las rejegas,
Inflalas, globos, pínchalas,
Sórbeles sangre y tuétanos,
Sécalas,
Cápalas,
Písalas, gallo galante,
Tuérceles el gaznate, cocinero,
Desplúmalas,
Destrípalas, toro,
Buey, arrástralas
Hazlas poeta,
Haz que se traguen todas sus palabras.

Las palabras

Octavio Paz (1968)

El poema es el lenguaje de los hombres, que durante miles de años se han servido de palabras, las han desplumado, las han destripado, han hecho que los lectores se las traguen todas para expresar todo cuanto es posible e imposible. El poema de Paz es una muestra del uso de la palabra y de la infinidad de formas que tiene. Refleja visiones de mundo, sentimientos, imágenes religiosas, sagradas, profanas, voces de protesta, de inconformidad, de aceptación, preceptos morales... Es decir, el poema es la voz universal. El elemento común entre diferentes épocas y culturas. En otros términos, "el poema es un caracol donde resuena la música del mundo y metros y rimas no son sino correspondencias, ecos, de la armonía universal" (Paz, 2003, p. 13).

\section{Imagen literaria}

Al poeta le urge hablar de las verdades que ve y que siente. Su creación de imágenes literarias lo lleva a formar un nuevo significado de las palabras, un onirismo nuevo. "Como los alquimistas"1, buscarán la "palabra filosofal", esa que tenga magia del ser y diga sobre el ser humano. Para esto, comulga con esa revelación, que fue destello, que le ofrece el ensueño; es decir, de esa conciencia escrita, transforma y vuelca la palabra sobre el ser. Y ahí en el poema se convierten en Judas, serán Calibán: expatriados, deformados, para luego tejer y destejer. Los poetas tejen y destejen sus experiencias, traen matices, rasgos de una felicidad cósmica (Bachelard, 2011). No destilan lo malo de lo bueno, sino utilizan las palabras para crear ensueños. Aumentan la riqueza de la lengua, "diré a mi vez las cosas eternas" y la trasmiten del ser humano al ser humano. En eso consiste llevar al aula el poema: transmitir desde la sangre, desde los huesos, desde la piel. Para recrear la vida, para hacer saber a los estudiantes que somos seres cósmicos hechos de carne y de nervios. "(...) cuando amamos el poema nos aplicamos a darle raíces oníricas y de este modo la poesía alimente en nosotros ensoñaciones que nunca habíamos sabido expresar" (Bachelard, 2011, p. 240). Construir a un amante de la poesía, no a un científico de ella, es la misión desde el aula poética.

\footnotetext{
1 Versos del poema Browning resuelve ser poeta (1995), de Jorge Luis Borges (1899-1896).
} 
Por otra parte, el poema está hecho de imágenes literarias que llevan al lector a la ensoñación poética. La plasticidad de su lenguaje es un tejido de arquetipos, recuerdos, percepciones que son encontrados y renovados, desde la imaginación. El ser humano está plasmado en cada palabra, en cada aliento poético; en la lectura retumban, resuenan, los ecos de los imaginarios tanto del poeta como de su lector. Este último se hace partícipe de esta creación, en una dialéctica de la lectura (Iser, 1987). En el aula poética se pretende darle paso a la imaginación, y para eso es necesario desarrollar una didáctica de la simple habilidad de escuchar el poema. Abrir las puertas al poema en el salón de clase significaría entrar en la relación de lo humano con el cosmos. Es darle la posibilidad de un encuentro, donde el lector sea afectado por lo que lee, desde su propia experiencia, donde no es necesaria una erudición del poema. Esto lo expresa Bachelard (2011) en su ensoñación poética: que la extrañeza y maravillarse estén unidos con el reposo del alma, que sean el objetivo principal. El poema en el aula es motivar hacia una experiencia poética.

\section{Experiencia estética}

El goce no se puede desligar de la experiencia artística, como tampoco alejarse de las acciones cotidianas: es la mejor manera de vivir el día a día, de la mano del disfrute y de hacer amena cada acción. ¿Por qué no gozar con el trabajo que se realiza? ¿Por qué no complacerse mientras se reflexiona el arte? Uno de los mayores intereses del presente trabajo es lograr que a partir del placer estético se generen diversas maneras de experimentar y pensar la poesía como fenómeno estético. Por tal razón, el disfrute es el punto de partida de la experiencia estética que se quiere generar y analizar. De esta manera, es fundamental el postulado que propone Jauss (2002): al poseer una actitud de goce se está desencadenando una experiencia estética primordial que bien puede convertirse en elemento de reflexión teórica y académica.

Llegados a este punto, es necesario preguntarse: ¿Qué clase de experiencias pueden posibilitarse en un aula de clase en torno a la poesía? Para dar respuesta al cuestionamiento, se tematizará respecto a tres planos fundamentales dentro de la experiencia estética, y los cuales se enmarcan dentro de las experiencias básicas: conciencia productiva, conciencia receptiva y experiencia (Jauss, 2002).

La aisthesis implica una relación directa obra-receptor, en la que el receptor, al percibir la obra, cumple una función hermenéutica. En otras palabras, él es el encargado de interpretar la obra, de descubrir lo que está presente en ella, pero también, lo que no se aprecia a simple vista. Con este plano estético se logra una función descubridora, en la cual el receptor es el actor principal que atraviesa por una experiencia sensorial que le permite satisfacer sus sentidos mediante la contemplación de lo bello; debe quedar claro que la contemplación no se limita al simple disfrute de lo bello con el fin de satisfacer momentáneamente los sentidos y obtener un placer banal. Si bien es cierto, como ya se planteó, el goce posibilita una experiencia estética primaria, es importante enfatizar que no debe quedarse en este campo, y es fundamental que trascienda al ámbito de la reflexión.

Teniendo claro el concepto de aisthesis y el proceso que esta experiencia implica, se continuará con la profundización en la experiencia intersubjetiva: catarsis. Esta es la posibilidad que tiene el receptor de entablar una comunicación con el autor, mediado por la obra de arte, alcanzando el goce de las emociones provocadas por la contemplación y la reflexión de dicha obra. A partir de la dialéctica establecida, el espectador de la obra puede generar diversas reacciones, que pueden ir desde el cambio de sus convicciones hasta la identificación con el autor o la liberación de su ánimo (Jauss, 1986).

La catharsis, como experiencia estética, puede darse en un doble sentido: como primera medida, en el ámbito del sujeto espectador, que desde la recepción de una producción estética puede gozar, comprender sus emociones, cambiar o reafirmar convicciones. En una segunda instancia, la experiencia cathartica se genera en el acto de creación estética: poiesis, pues el autor de la obra de arte expresa mediante su producción lo que acontece en su interior. A saber, le permite liberarse de cuanto considera que es importante dar a conocer al mundo. Es así como la liberación mediante 
la producción estética le posibilita al autor el placer de la contemplación de su creación, y, más importante aún, hacer de su mundo su propia obra.

La última experiencia estética por tematizar es la poiesis, entendida como la capacidad productiva que tienen los hombres de crear una obra de arte. En la experiencia de producción estética, el artista ocupa el papel fundamental, por ser en su proceso de creación como logra hacer de su mundo y sus vivencias su propia obra de arte. Tal situación no solo le genera la liberación de su ánimo, sino que también le brinda la posibilidad de sentir placer al concebir su mundo como su propia obra.

La capacidad del artista de crear obras de arte obedece a una práctica vital del ser. Desde su interior, reconstruye el mundo exterior a partir de un proceso de interpretación y revaloración de la realidad. De esa manera, se puede afirmar que la poiesis cumple una función hermenéutica, en la medida en que posibilita la comprensión del mundo y la concepción de uno nuevo mediante la obra. En ese sentido, es válido retomar las palabras de Juan Liscano (2009) para referirse al poeta: "El poeta es siempre un subversivo y un explorador, siempre en demanda de la otredad, del más allá, del mito y de la metáfora".

Es, justamente, en estos tres elementos en los que se entabla una comunicación literaria, logrando que el sujeto alcance el ámbito de la creación libre, la liberación de sí y la identificación con la obra de arte.

Dije, maiz. Generaciones de indios fueron rescatadas del olvido.

Dije, palma. Largas elaboraciones de tejidos, milenios de substancias fibrosas ataron el pasado con el presente.

Dije, arcilla. Se mostraron las tinajas de hinchado vientre de mujer encinta, los platos y cazuelas como discos solares arrojados hacia el porvenir. Dije, río. Fluyeron las aguas del diluvio. Fueron ahogadas las razas. Sobre las primeras tierras emergidas y chorreantes, cruzó un pájaro. Dije, selva. Torrencial follaje, explosiones de verdor, vahos zumbantes, tibieza de matriz. El silencio sin rostro y con cuerpo de hormigas voraces aullaba entre pieles de sierpes como vainas, caídas de los árboles.
Dije, llanura. Giraron embudos de vientos negros. Se quebró una luz de cristal o de leño seco. Un espejismo de mercurio relucía en el horizonte.

Dije, luna. Brotaron fuentes e hilillos de leche, se abultaron humedades, proliferaron hongos, mohos, légamos y se escucharon grandes caídas de agua. Dije, mujer. Un tallo de venas rotas echó una flor.

Dije, hombre. Se alzaron escudos y macanas, brillaron filos y puntas de hueso, flotaron los plumajes, pero en alguna parte del combate se abrió una mano como delta.

Dije, sol. Truena el verano, un ave deslumbrante e invisible pasa y sólo se mira su sombra. Muestra el cielo una faz roja y rugiente.

Dije entonces, Dios, comiéndome las palabras, con la lengua volteada hacia adentro y con los ojos vaciados.

El amor era un tigre en acecho

La muerte se acercaba lentamente bajo una nave de árboles estrellados.

América

Juan Liscano (1985)

América es un poema que alude a la identidad cultural de Suramérica. Por tanto, tras su lectura, el receptor podrá entablar un diálogo con Liscano, donde el tema central será el ser americano: sus raíces y su sentir serán proyectados en su ser. Así, el lector puede verse abocado a la reflexión sobre el origen de este pueblo y las diferentes condiciones que han logrado que los pobladores dejen en el olvido su cultura ancestral. Para llegar al sentido del poema, no es necesario tener claros concretos históricos: el mismo texto los produce. Y entabla una comunicación entre obra y lector.

En cada uno de los versos iniciados con la palabra "Dije", el autor logra que sus receptores se transporten a ese pasado que permite descubrir y reencontrarse con los elementos propios y significativos de dicha cultura; maíz, arcilla, palma no son solo sustantivos: son la representación del alimento, de la artesanía, del comercio, de la tradición cultural de un pueblo. Hacen alusión a la geografía propia de América; río, selva y Ilanura son los espacios en los que se asentaron miles de indígenas, y que hoy día se han transformado en ciudades y terrenos de explotación. Ni hombre ni mujer asumen el papel simple de habitantes: las mujeres 
aportan el quehacer diario, lo magnífico salido de lo simple; y los hombres representan la lucha, la batalla que se ha gestado por mantener viva una cultura, por defender un territorio, la dignidad de un pueblo.

Sol y Dios evidencian la relación de los hombres con los elementos míticos, religiosos, con ese más allá de la tierra y de la vida. Por último, el amor, elemento sorpresa que, quizás, es uno de los más grandes sentimientos nacidos en el interior del ser. Y después de todo, en este recorrido, el hombre inevitablemente condenado a la finitud. Con su poema, Liscano logra que el receptor vuelva la mirada al continente americano, a lo que es hoy, transformado por la globalización. Por la hegemonía, por tantos elementos que han hecho olvidar esa tradición propia de cultura indígena, tras esta reflexión el lector puede llegar a identificarse con ese origen y recocerse en él como sujeto social, como americano, como heredero de toda esta riqueza.

\section{Afectación del lector}

Iser (1987) habla de las diferentes afectaciones que le suceden al lector en el momento de leer. En este caso, el poema, como texto, está lleno de vacíos e indeterminaciones, que llevan al poelector a representarlos; es decir, con lo no-dado en el texto. Los signos lingüísticos presentan un contexto inseparable que se crea con la imagen de representación y lector (Iser, 1987). Este sujeto se ve afectado por ese contexto; al estar presente en la constitución de las imágenes, que indicaría representación de lo no-dado, significaría que el lector está fuera de la realidad. Así, en esta irrealidad durante la lectura se debe dar la coherencia en un despertar. Al darse esta estimulación, "(...) el mundo propio se nos muestre como una realidad observable" (Iser, 1987, pp. 224-225). Y, de esta manera, la configuración de sentido se vuelve una experiencia.

El lector debe eludir su propia experiencia personal, en el mismo acto de leer. Debe ser receptivo, suspender todo su ser y utilizarlo para constituir el sentido. Al mismo tiempo, le podrá acaecer algo. Mientras tanto, los aspectos del texto deben ser un medio para esta constitución; si no es así, el texto se convierte en una simple reconstrucción histórica (Iser, 1987). Como ejemplo de esta representación, el poema de Piedad Bonnet:

El sol del mediodía, su luz sonámbula,

El recio azul del cielo tirante y sordo, El aire y su ondulante resplandor de hojalata,

Las vacas tardas, tontas, en el verde infinito, $Y$ las moscas zumbonas, Tornasoladas,

Su círculo de muerte coronando el silencio;

Los ojos como espejos, y en los ojos, El ave circular, la nube pasajera; $Y$ las manos atadas, Y la tierra

Donde crecen los yuyos fieramente, Las zarzas, el jaramago, las madreselvas. Todo esperando el lente del fotógrafo; $Y$ a lo lejos la risa de las hienas.

Paisaje

Piedad Bonnet (2012).

El pensamiento descrito en el poema, el calor sofocante y el cielo silencioso responden al cómo será lo descrito percibiendo un dolor que está impregnado en el poema. Este Paisaje mostrado por Piedad Bonnet implica imaginarse, conlleva un "intento de representarse lo que como tal jamás puede ser visto" (Iser, 1987 , p. 219). Las moscas zumbonas/tornasoladas/su círculo de muerte coronando el silencio/, estos versos reclaman al lector una representación de la cotidiana violencia en Colombia: se representa a la muerte desde las moscas, desde la carroña, haciendo parte de esas imágenes que están presentes en los colombianos.

Lo no dado en el poema es lo que conlleva la imagen haciéndola presente. Esto cambia y se va perfilando aún más: y las manos atadas/ y la tierra/ (...) Todo esperando el lente del fotógrafo; / y a lo lejos la risa de las hienas. Muerte causada, muerte sin salvación, muerte en manos del poder. Y periódicos que dicen, sin decir nada, porque el silencio reina convirtiéndose en impunidad; representada en ser humano atado y con un tiro de gracia. El lector debe hacerse partícipe proyectando su subjetividad, su dolor, su conocimiento de este país, relacionando lo no-dado con ello, dejándose afectar, dejando que le acontezca el dolor de los versos: los ojos como espejos, y en los ojos, / el ave circular, la nube pasajera; / y las manos atadas, / y la tierra/. Al crear esta imagen, recorre el miedo, la impotencia de la muerte. 


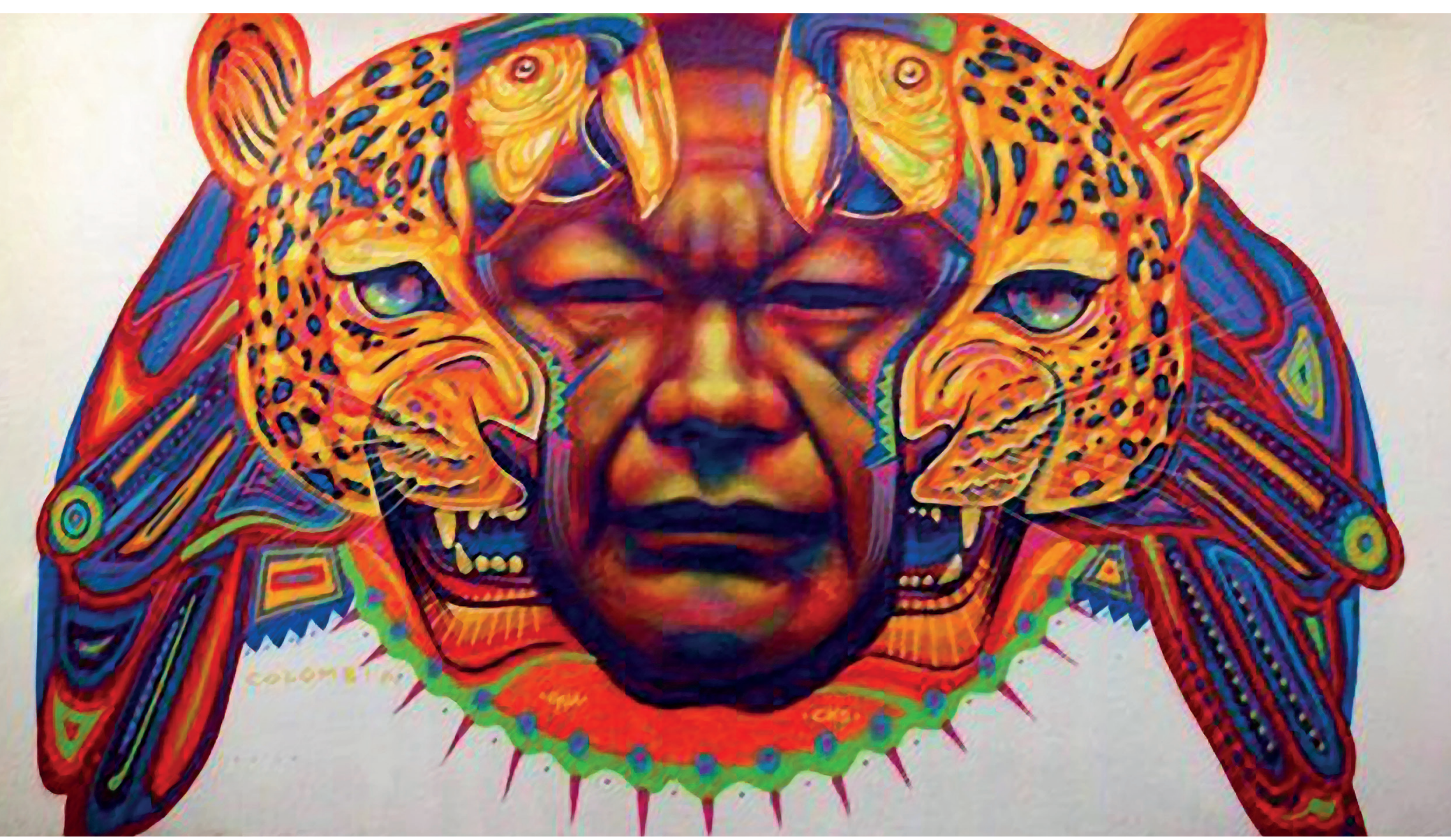

Artista: Guache 
Pensar en el acto de la lectura como lo extraño que todavía no se ha experimentado, no solo significa que se debe interpretar: significa también que estos actos de interpretación tienen éxito en la medida en que se formule o acaezca algo al sujeto-lector. Esta afectación moviliza al lector hacia la espontaneidad de ánimos, conductas, voluntades, valores; y de esta manera se formulan las ideas de otros, ideas extrañas en la conciencia del lector, en su caudal experiencial, que así se convierten en tema. Sumado a ello, la constitución de sentido no solo tiene que ver con el sentido que está inmerso en el texto, pues también se relaciona con la posibilidad que tiene el lector de formularse, para descubrir algo de lo cual no es consciente antes del acto. Esto es lo que la literatura ofrece: formula al ser humano desde otras posibilidades (Iser, 1987).

Para concluir, las dialécticas que ocurren en el texto poético ayudan a la formulación de nosotros mismos. Por medio de la espontaneidad que provoca las estrategias del texto y por la representación de lo no-dado, se descubren otros elementos que no hacían parte de nuestra conciencia. La literatura completa su acción cuando se hace consciente en el lector. Es desde aquí desde donde el presente trabajo educativo es altamente imperativo. En la poesía se halla ese encontrase, se hace evidente — como ya se ha dicho- el encuentro con los estudiantes, un encuentro humano, un llegar a la conciencia, a partir de la afectación estética de la lectura de poesía.

\section{Encuentros}

Se pensó en tres talleres con el objetivo de desarrollar la experiencia lectora y la experiencia estética desde el poema. Estos apuntaban a acercar a los estudiantes a las características propias del poema, a través de las diferentes formas de recreación de los textos propuestos, tales como: la lectura modelada, la declamación por parte de los estudiantes, la escucha desde diferentes voces (canciones, poetas y puesta en escena). Estos encuentros poéticos llevados a cabo arrojaron los siguientes resultados: la relación entre poema y canción vistas como expresiones de la sensibilidad del ser. También, la re-significación de lo poético como tipo de texto con estructura determinada, y diferentes experiencias suscitadas por la re-creación del poema partiendo del goce.
En cuanto a la relación de poema y música, los estudiantes del grado noveno justifican la música como poesía, en la medida en que parte de la emoción del ser. Esta puede concretarse mediante el uso de la palabra y da cuenta de la intimidad, despierta lo nocturno; es decir, lo que se esconde en el orden diurno (Larrosa,1996), manifiesta lo que es propio de cada sujeto. Un ejemplo de ello es lo que manifiesta el estudiante Alexander Dokoe:

[...] él no decía las palabras por decirlas, sino las sentía, si, entonces él tiene, bueno él tiene el momento de escribir esa poesía o esas canciones o esas letras que él componía. Él no sólo decía las cosas, las decía porque sí, las sentía adentro del corazón de él, como una emoción y... ¡Huy, profe!, es algo inexplicable (risa, cara de alegría, de emoción). (Referido a la canción de Cancerbero, Te Quiero, trabajada en el primer taller.)

Es así como los estudiantes, implícitamente, manifiestan el concepto de lo poético: desde sus vivencias y su sentir. Al expresar "las sentía adentro del corazón de él, como una emoción y... ¡Huy, profe!, es algo inexplicable", evidencia el material íntimo de la poesía, expresa la sensibilidad del poeta que le permite transformar su emoción en obra (Paz, 2003).

En los talleres aplicados, los estudiantes entablaban un diálogo con el texto para llegar a formar una representación; es aquí donde la comprensión del poema se evidencia y se concretiza (Iser, 1987) realizando un proceso de doble sentido, que va desde lo cognitivo permeado por lo emotivo.

Estudiante Cristian Pachón: a mí me parece que... trata de decir que el televisor para él siempre ha estado dañado; o sea, que si no lo manda a arreglar, eso es como un pretexto para decir que está dañado...

Profesora Mileydi: o sea, ¿para que siga dañado?

Estudiante Cristian Pachón: ¿para qué está dañado? Igual, está siempre dañado; como que no hay lo que él quiere ver, o algo así...

Profesora Mileydi: ¿no es como lo mismo?... 
Profesora Viviana: o sea, ¿lo que tú nos estás diciendo es que estar dañado es una excusa para qué?

Estudiante Cristian Pachón: para no verlo.

El poema relacionado aquí es Me preocupa el televisor, de Jaime Sabines (2001). El tema construido por el estudiante Cristian Pachón da cuenta de la dialéctica entre poesía y lector, donde el segundo actualiza el poema presentado brindando nuevos conocimientos; es decir, re-significando el sentido. Iser (1987) expresa que en esta interacción es donde se evidencia el efecto estético. Así, el aula poética aporta a la construcción del objeto estético, desde los actos de significación.

A lo largo de los talleres aplicados se evidenció el gusto de los estudiantes por la lectura oral de los poemas. En ellos encontraron elementos de identificación que les permitieron conectar el poema con su ánima (Bachelard, 2011). Situaciones como el amor, el erotismo, el orgullo; en otras palabras, la condición humana. Tras la escucha de los poemas, varios estudiantes solicitaron hacer la relectura del texto, pues les generaba placer leerlo y poder darle musicalidad (Vásquez, 2002). Así, la voluntad de hablar se convertía en una reclamación de la poesía con las intuiciones primitivas, y convirtiéndose el verso en el aire que respira (Bachelard, 2012).

Uno de los poemas trabajados fue $Y$ Dios me hizo mujer, de Gioconda Belli (2011). Tras su lectura, se observó el interés no solo de las niñas por el poema, sino también, el de los estudiantes hombres, pues al solicitar que se hiciera una representación de los diferentes poemas abordados, el alumno Luigi Daza decide tomar este poema. Él dibuja a una mujer en el agua, en vestido de baño, poniendo en evidencia su sensualidad, y relacionándolo con el hecho de ser mujer. Se puede observar que el estudiante toma este poema con el fin de dar a conocer la importancia de la mujer en su vida y los elementos que de ella le atraen. Despertando así en el hombre el ánima, la parte femenina y la sensibilidad.

Del poema surgen experiencias, múltiples experiencias: personales, sociales y de conocimiento. Los hallazgos permiten entender que el texto poético trasciende el campo de lo sensible, del ensueño, y se traspasa al ámbito cognitivo, pues propicia el pensamiento reflexivo, la apropiación del lenguaje y la interpretación de la palabra. Los estudiantes, con el paso de los días, fueron demostrando mayor facilidad para entender lo implícito de los poemas, las temáticas de estos, la intencionalidad de los poetas, debatieron entre ellos y compartieron sus opiniones. Las experiencias estéticas básicas facultadas por la participación de los poemas se complementaron con experiencias de conocimiento.

Evidentemente, la poesía debe tener un papel importante dentro de las aulas de clase; esa es la invitación que "aula poética" hace a los diferentes actores escolares. Es claro que la escuela debe cumplir con el desarrollo de un programa curricular, y que los profesores de literatura tienen que abordar muchos más contenidos; sin embargo, para quienes quieran incluir la poesía en su diario quehacer o asumirla como temática de su plan de trabajo, esta investigación, les propone una didáctica que parte de acciones sencillas como la lectura y la lúdica y profundiza en el taller literario.

En conclusión, al darle la bienvenida al poema en las aulas escolares, también damos ingreso a la condición humana de los estudiantes. Es reconocer la sensibilidad, la experiencia y los conocimientos que ellos poseen. Es abrir la ventana para la imaginación teniendo la posibilidad de encontrase con ellos mismos y re-significar el mundo que habitan, como también re-significarse desde su propia naturaleza humana. 


\section{Referencias}

Bachelard, G. (2011). La poética de la ensoñación. México: Fondo de Cultura Económica.

Bachelard, G. (2012). El aire y los sueños. México: Fondo de Cultura Económica.

Belli, G. (2011). Sobre la grama. Bogotá: Norma.

Benedetti, M. (2001). El mundo que respiro. Bogotá: Planeta Colombia.

Bonnett, P. (2012). Eudoria. En R. Quintero. El país imaginado. Bogotá: Trilce.

Borges, J. L. (1995). Antología poética 1923-1977. Madrid: Alianza.

Carranza, M. (1995). De amor y desamor y otros poemas. Santafé de Bogotá: Norma.

Frost, R. (2013). Poesía y escuela. En C. Fajardo (Comp.). Poéticas del siglo XX, (pp. 143-148). Bogotá: Ediciones Desde Abajo.

Goyes, J. (2012). La imaginación poética: afectos y efectos en la oralidad, la imagen, la lectura y la escritura. Colombia: Caza de Libros.

Iser, W. (1987). El acto de leer. Madrid: Taurus.

Jauss, H. (1986). Experiencia estética y hermenéutica literaria: ensayos en el campo de la experiencia estética. Madrid: Taurus.
Jauss, H. (2002). Pequeña apología a la experiencia estética. Barcelona: Paidós.

Jiménez, C. (2004). La lúdica como experiencia cultural. Bogotá: Magisterio.

Larrosa, J. (1996). La experiencia de la lectura. Barcelona: Laertes.

Liscano, J. (1985). América. En J. Cobo (Comp.). Antología de la poesía hispanoamericana. México: Fondo de Cultura Económica.

Liscano, J. (2009, 14 de julio). Sobre poeta y poesía [weblog post] Recuperado de: http://grupolipo.blogspot.com

Nervo, A. (1997). Niños vamos a cantar. En S. Andricaín y A. Rodríguez. Escuela y poesía. Bogotá: Magisterio.

Niño, J. (1986). La alegría de querer. Bogotá: Carlos Valencia Editores.

Paz, O. (1968). Libertad bajo palabra: obra poética. México: Fondo de Cultura Económica.

Paz, O. (2003). El arco y la lira. México: Fondo de Cultura Económica.

Sabines, J. (2001). Algo sobre la muerte del mayor Sabines; Maltiempo; Otros poemas sueltos. México: Joaquín Mortiz.

Vásquez, F. (2002). La enseña literaria: crítica y didáctica de la literatura. Bogotá: Kimpres.

Vásquez, F. (2014, 18 de julio). La poesía vuelve a la escuela [web log post] Recuperado de: http://fernandovasquezrodriguez.com 


\section{Diálogo de conocimiento}

En este valioso texto que parte de los conceptos de experiencia estética y experiencia de lectura, suscitados a partir del encuentro poético en el aula; se sugiere una reflexión en torno al papel de la poesía en la escuela y las formas de evocarla dentro del aula. Nos revela una experiencia donde prima la emoción, desatada por el poema, haciéndose evidente una recepción y afectación hacia lo más profundo y sensible del sujeto; generando ante todo placer estético a partir de escuchar al otro, de leer a ese otro que quiere transmitirme un mensaje, un placer que invita a la creación de mundos posibles, donde las y los jóvenes se reconcilian con su espíritu, enriqueciendo su forma de sentir y su manera particular de ver el mundo y de verse a sí mismos reflejados en las palabras e historias... de ver, reconocer a los otros y reconocerse en los otros.

Retomando las palabras del maestro Fabio Jurado: la literatura y la poesía son vías para que las niñas y niños y las y los jóvenes puedan pronunciar sus mundos y exteriorizar sus ideales. La poesía es una ruta expedita para lograr la sensibilidad de los estudiantes y comprender la complejidad del mundo a través de ese acento figurativo y simbolico que le caracteriza; el joven entonces, lee, escucha su dialogo interno....se pregunta...se emociona... y surge de su interior la motivación creativa por escribir, por plasmar su sentir... por dejar huella, por ser.

La tarea del docente aquí reflejada es la creación del camino para entrar en esos mundos, habitarlos, hablar de ellos, re significarlos, en una ruta que invita finalmente a la propia creación; que tiene como pretexto la lectura de la poesía, y el taller literario como medios para reconocer la sensibilidad; esa dimensión que determina nuestra condición humana.

Sandra Patricia Alvarado Garay 